\title{
Liposome encapsulation of doxorubicin and celecoxib in combination inhibits progression of human skin cancer cells
}

This article was published in the following Dove Press journal:

International Journal of Nanomedicine

\author{
Sanjay Singh \\ Institute of Life Sciences, \\ School of Science and Technology, \\ Ahmedabad University, Ahmedabad, \\ Gujarat, India
}

Correspondence: Sanjay Singh Institute of Life Sciences, School of Science and Technology, Ahmedabad University, Navrangpura, Ahmedabad 380009, Gujarat, India Email sanjay.singh@ahduni.edu.in

\begin{abstract}
Therapeutic agents aimed at inhibiting a single molecular target have not been successful in cancer therapy, but rather they impart resistance. However, multi-target inhibitors have shown promising results in circumventing the development of resistance and inducing apoptosis in cancer cells/tissues. In this study, we encapsulated doxorubicin and celecoxib in a single liposome at a ratio of 1:10. These dual drug-encapsulated liposomes showed excellent anticancer activity compared to individually encapsulated liposomes. The expression of key proteins such as AKT and COX-2 was suppressed, which suggests that doxorubicin and celecoxib synergistically inhibit multiple key signaling pathways.
\end{abstract}

Keywords: drug delivery, nanoliposomes, nanomedicines, cancer nanotechnology

\section{Introduction}

During the past few decades, there has been significant development in cancer treatment using chemotherapy, radiation therapy and surgery. ${ }^{1}$ Traditional methods of cancer treatment have limited success due to systemic side-effects, development of drug resistance and sub-optimal drug concentration at the tumor site. ${ }^{2}$ To increase the local drug concentration in tumor region, several strategies have been developed and are centered on targeting the cancer cells/tissues and oncogenes involved in controlling the proliferation and key survival pathways of cancer types. Several targeted monotherapies such as vemurafenib, trastuzumab, imatinib, gefitinib and erlotinib are successful in treating various cancer types. ${ }^{3}$ However, prolonged monotherapy results in the development of resistance due to multigenic abnormalities present in cancer cells. It has been reported that single-target inhibitors (STIs) cannot combat cancer; therefore, multi-target inhibitors (MTIs) are an attractive alternative as they have shown more efficacy and do not impart resistance compared to STIs. MTIs synergistically inhibit multiple pathways that are essential for the growth of cancer cells. Therefore, liposome encapsulation of such MTIs may offer several benefits such as improved solubility of hydrophobic drugs, natural retention of drugs at tumor site by enhanced permeability and retention (EPR) effect, enhanced circulating half-life and favorable pharmacokinetic behavior. ${ }^{4}$ In this study, we have synthesized liposomal formulation of two anticancer drugs, doxorubicin and celecoxib, which inhibit the protein kinase B (AKT) and cyclooxygenase-2 (COX-2) pathway respectively, that are overexpressed in human skin cancer cells/tissues. . $^{5,6}$ 


\section{Materials and methods Synthesis of liposomes}

Blank liposomes (BLs) were synthesized using phosphatidylcholine (PC) and 1,2-distearoyl-sn-glycero-3-phosphoethanolamine- $N$-[methoxy(polyethylene glycol)]-2000 (m-DSPEG) film hydration under $\mathrm{N}_{2}$ flow followed by redispersion of film in $1 \%$ saline solution. To synthesize doxorubicin encapsulating liposomes (Dox L) and celecoxib encapsulating liposomes (Cele L), the dried lipid film was rehydrated with phsophate buffer solution containing either doxorubicin or celecoxib was used. The doxorubicin and celecoxib encapsulating liposomes (Dox-Cele L) were synthesized by the aforementioned method except that the drugs were added in the ratio of $1: 10$.

\section{Characterization of liposomes}

Blank and Dox L and Cele L were characterized by dynamic light scattering, UV-visible spectrophotometer and transmission electron microscope.

\section{Determination of anticancer activity}

The anticancer activity of Dox L and Cele L was evaluated by 3-(4,5-dimethylthiazol-2-yl)-5(3-carboxymethonyphenol)2-(4-sulfophenyl)-2H-tetrazolium (MTS) and 5'-bromo-2'deoxyuridine (BrdU) assay. Different concentrations of Dox $\mathrm{L}$ and Cele $\mathrm{L}$ were exposed to human skin carcinoma (A431) cells (5,000 cells seeded in a 96-well plate) followed by the addition of MTS dye. The resultant water-soluble formazan color was read at $450 \mathrm{~nm}$. A431 cells were commercially purchased from National Centre for Cell Sciences, Pune, India.

\section{Results and discussion}

The BLs were $\sim 80 \mathrm{~nm}$ in diameter, whereas Dox L, Cele L and a combination of Dox L and Cele L (Dox-Cele L) (1:10) were $\sim 87 \mathrm{~nm}, \sim 86 \mathrm{~nm}$ and $\sim 88 \mathrm{~nm}$ in diameter, respectively (Table 1). It has been shown that nanoparticles of $\sim 80 \mathrm{~nm}$

Table I Size and zeta potential measurement of liposomes

\begin{tabular}{lll}
\hline Liposome type & $\begin{array}{l}\text { Size } \\
(\mathbf{n m})\end{array}$ & $\begin{array}{l}\text { Zeta potential } \\
(\mathbf{m V})\end{array}$ \\
\hline $\begin{array}{l}\text { Blank liposomes (BLs) } \\
\text { Doxorubicin-encapsulated } \\
\text { liposomes (Dox L) }\end{array}$ & $\begin{array}{l}80.6 \mathrm{I} \pm 2.9 \\
87.66 \pm 3.4\end{array}$ & $-46.5 \pm 3.2$ \\
$\begin{array}{l}\text { Celecoxib-encapsulated } \\
\text { liposomes (Cele L) }\end{array}$ & $86.34 \pm 4.5$ & $-50.6 \pm 4.6$ \\
$\begin{array}{l}\text { Doxorubicin and } \\
\text { celecoxib-encapsulated }\end{array}$ & $88.8 \mathrm{I} \pm 2.1$ & $-50.1 \pm 5.1$ \\
liposomes (Dox-Cele L) & & \\
\hline
\end{tabular}

Notes: Data presented as mean \pm SD.

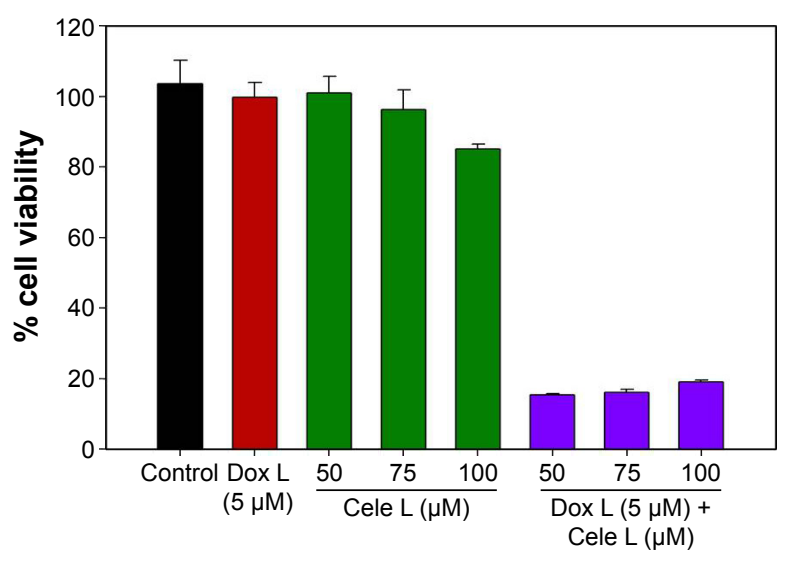

Figure I MTS assay showing significant decrease in A43 I cell viability when exposed to Dox-Cele L than Cele L or Dox L alone.

Abbreviations: Cele L, celecoxib-encapsulated liposomes; Dox-Cele L, combination of doxorubicin- and celecoxib-encapsulated liposomes; Dox L, doxorubicinencapsulated liposomes; MTS, 3-(4,5-dimethylthiazol-2-yl)-5(3-carboxymethonyphenol)-2-(4-sulfophenyl)-2h-tetrazolium.

diameter are internalized the most by cancerous cells/tissues and produce EPR effect. ${ }^{4}$

Compared to BL, the increase in diameter of Dox L, Cele L and Dox-Cele L demonstrate the successful encapsulation of drugs. Furthermore, the high negative zeta potential values imply high stability of these liposomes in aqueous suspension.

Encapsulation of drugs did not alter the zeta potential values considerably, which indicates that drugs are present in the internal cavity of liposomes and not physically adsorbed on the surface of the liposomes. We estimated cell viability on A431 cells by two methods: MTS (Figure 1) and BrdU (Figure 2) assay. MTS assay using A431 cells clearly demonstrated that Dox $\mathrm{L}$ at $5 \mu \mathrm{M}$ concentration did not cause any decrease in cell viability, whereas Cele L at $100 \mu \mathrm{M}$,

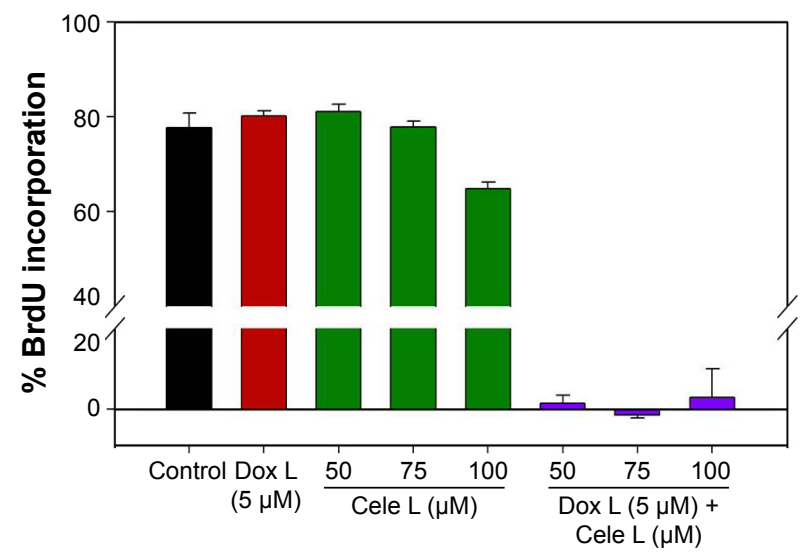

Figure $2 \mathrm{BrdU}$ assay showing exposure of Dox-Cele $\mathrm{L}$ greatly reduced the cell proliferation in $A 43 \mathrm{I}$ cells than Cele $\mathrm{L}$ or Dox $\mathrm{L}$ alone.

Abbreviations: BrdU, 5'-bromo-2'-deoxyuridine; Cele L, celecoxib-encapsulated liposomes; Dox L, doxorubicin-encapsulated liposomes. 
$75 \mu \mathrm{M}$ and $50 \mu \mathrm{M}$ concentrations induced $18 \%, 7 \%$ and $3 \%$ decrease in cell viability, respectively.

Interestingly, Dox-Cele $\mathrm{L}$ that consisted of doxorubicin $(5 \mu \mathrm{M})$ and celecoxib (ranging from $100 \mu \mathrm{M}$ to $50 \mu \mathrm{M}$ ) induced significant $(>90 \%)$ decrease in cell viability. This observation was further confirmed by BrdU incorporation assay (Figure 2). The results of BrdU assay showed that when used alone, $5 \mu \mathrm{M}$ concentration of Dox L and $75 \mu \mathrm{M}$ and $50 \mu \mathrm{M}$ of Cele $\mathrm{L}$ did not induce any cytotoxicity against A431 cells; however, $100 \mu \mathrm{M}$ of Cele L showed $\sim 20 \%$ decrease in cell viability. Conversely, a combination of doxorubicin and celecoxib in single liposome (Dox-Cele L) showed $>99 \%$ decrease in cell viability. This observation clearly suggests that the co-exposure of doxorubicin and celecoxib is much effective than either of the drugs used alone. It has been well documented that AKT and COX-2 pathways are key regulators of cancer cell progression, metastatic spread and even tumor initiation. Doxorubicin is a known inhibitor of AKT pathway and celecoxib inhibits COX-2 pathway; therefore, co-exposure of these two drugs possibly might have suppressed the expression of AKT and COX-2 simultaneously, leading to cell apoptosis.

\section{Conclusion}

Liposomes ratiometrically loaded with combinations of doxorubicin and celecoxib were successfully synthesized in this study. These dual drug-loaded liposomes were able to inhibit the cancer cell viability up to $>99 \%$ even at lower concentrations, which were ineffective when used alone. The co-exposure of doxorubicin and celecoxib might have synergistically inhibited the AKT and COX-2 pathways leading to cell apoptosis.

\section{Acknowledgment}

The financial assistance for the Centre for Nanotechnology Research and Applications (CENTRA) by The Gujarat Institute for Chemical Technology (Grant no ILS/GICT/2013/003) is gratefully acknowledged.

\section{Disclosure}

The author reports no conflicts of interest in this work.

\section{References}

1. Smalley KSM, Herlyn M. Towards the targeted therapy of melanoma. Mini Rev Med Chem. 2006;6(4):387-393.

2. Duncan R. The dawning era of polymer therapeutics. Nat Rev Drug Discov. 2003;2(5):347-360.

3. Gowda R, Jones NR, Banerjee S, Robertson GP. Use of nanotechnology to develop multi-drug inhibitors for cancer therapy. J Nanomed Nanotechnol. 2013;4(6):184-219.

4. Singh S, Sharma A, Robertson GP. Realizing the clinical potential of cancer nanotechnology by minimizing toxicologic and targeted delivery concerns. Cancer Res. 2012;72(22):5663-5668.

5. Cao Y, Ruan Y, Shen T, et al. Astragalus polysaccharide suppresses doxorubicin-induced cardiotoxicity by regulating the PI3k/Akt and p38MAPK pathways. Oxid Med Cell Longev. 2014;2014: 674219-674230.

6. Wu T, Leng J, Han C, Demetris AJ. The cyclooxygenase-2 inhibitor celecoxib blocks phosphorylation of Akt and induces apoptosis in human cholangiocarcinoma cells. Mol Cancer Ther. 2004;3(3):299-307.
International Journal of Nanomedicine

\section{Publish your work in this journal}

The International Journal of Nanomedicine is an international, peerreviewed journal focusing on the application of nanotechnology in diagnostics, therapeutics, and drug delivery systems throughout the biomedical field. This journal is indexed on PubMed Central, MedLine, CAS, SciSearch ${ }^{\circledR}$, Current Contents ${ }^{\circledR} /$ Clinical Medicine,

\section{Dovepress}

Journal Citation Reports/Science Edition, EMBase, Scopus and the Elsevier Bibliographic databases. The manuscript management system is completely online and includes a very quick and fair peer-review system, which is all easy to use. Visit http://www.dovepress.com/ testimonials.php to read real quotes from published authors. 